\title{
"Campaigns of Curiosity": Class Crossing and Role Reversal in British Domestic Service, 1890-1950
}

Lucy Delap

\author{
'I became one of those women...'1
}

\section{Role Reversal}

In 1889, the British Weekly sponsored an investigation into London working women, with a strong emphasis on the relationship between mistresses and servants. At a meeting arranged to hear the servants' side of the matter, the journalist asked for ways by which "a better understanding can be brought about between servants and mistresses": "In my opinion,' said a rather solemn-looking man, 'someone ought to write a book like "Vice Versa," and put the mistress in the servant's place.." This proved to be a prescient remark; Vice Versa, a recently popular novel, featured a tyrannical father who exchanged places with his son. ${ }^{3}$ It invoked an idea of role reversal or 'changing places', which had long been, and continues to be, a powerful cultural device, recurring in folk songs, fairy tales, literary narratives, and social commentary. The power of a Cinderella plot, Tichborne case or a Mills and Boon romance is based on the sentimental appeal of rags to riches narratives; riches to rags has proved just as compelling. Role reversal plots draw power from the disjuncture caused by social mobility, and transgression of boundaries. Accounts such as George Orwell's impersonation of a 'down and out' rest on the idea that in 'changing places', one adopts a role as an outsider, an onlooker in 'another life'. There is an epistemic advantage in role reversal, whether one shifts from a position of power and social esteem to one of marginality, or vice versa. Many accounts are humorous in their portrayal of inappropriate behaviour in 'changing places'. Others use changing places to focus critically on hypocrisy and double standards.

In this paper, I investigate a set of narratives of role reversal in the realm of domestic service, spanning the late nineteenth-century to the mid-twentieth. Such accounts are historically interesting because they form a part of a cultural genre, 'the servant question'. This compelling and apparently irresolvable social question formed an important social imaginary within British society for at least three centuries, as a vehicle for discussion about status, authority and social change. ${ }^{4}$ This paper draws attention to role reversal as a particular element in the ongoing process of establishing identities and idioms of class, both as a fantasy and occasional social experiment. While never able to resolve the ambiguities of class, role reversal had a persistent and profound fascination for many middle class women who kept servants. Those women who 'passed' as working class servants were attempting to stabilize the identities of mistress and servant through transgression, though they were also pursuing individual psychic satisfactions and social 
authority - the ability to impersonate and speak for working class women, to describe 'middle classness' and align it with servant-keeping, and prove the capacity of middle class women to do domestic work.

Keeping servants had been used by Seebohm Rowntree in 1901 as the 'great divide' between the working classes and all others, and service continued to be among the most important of markers of class, particularly for establishing class distinctions between women. ${ }^{5}$ As a writer in the Nineteenth Century put it in 1900, "of all classes of women the only ones who are addressed without the prefix of Miss are servants. ... it is interesting and instructive to note that this is actually the only clear dividing line of social class that is left among us in the present day." Service offered a multifaceted way of talking about social distinctions, observed in the dress, naming, speech, physical characteristics, moral character, and habits of servants. As late as 1940, it was still possible for a commentator to observe that domestic service was the ideal sector in which to show the deep class divisions of Britain because "it is here that class distinctions are most forced into prominence."”

The middle class home played a central role in the establishment, contestation, and reformulation of class in twentieth-century Britain. ${ }^{8}$ As in previous centuries, this was deeply bound up with formulations of gender. As both a private, intimate realm, and a workplace, the homes of servant-keeping women hosted confrontations between women of different classes, the dynamics of which are rarely available to historians. Role reversal and impersonation narratives allowed women to explore and record the nuances of such confrontations. Some middleclass women developed voice or expertise through impersonation, to counter the erosion of certainty about the markers of class that was implicated in the twentieth-century decline of domestic service. But role reversal narrative gestured towards a version of class, which was quite distinctive to the institutions of domestic service_-class as a moral order, a somatic regime, an emotional landscape. And in this formation, women were central interpreters and keepers of boundaries.

The stories that follow remind us of the literal performance and spatial enactment of social class, as well as its establishment in fantasy and the imagination. In their narration, they make visible the evolution of languages of class which were quite tangential to the relations of production and political or civic activism with which class has traditionally been associated. Nonetheless, the irresolvable tensions in these performances and the clumsy and ill-fashioned nature of these attempts to describe class relations played out between women in domestic settings alerts us to the ever-ambiguous nature of keeping servants in these decades. Role reversal performances were as much about the disintegration of class certainties as their establishment.

Servant-keeping in Britain, while in decline in absolute numbers, still employed at least a third of the female labour force for the first four decades of the twentieth-century. The nineteenth-century 'servant problem' had been domi- 
nated by issues of the supply and failings of servants. In the twentieth, it came to reflect an intense fear of blurring the distinctions between servant and non-servant. Service had become increasingly feminised and general, with the predominance of the single servant-a 'maid-of-all-work', 'slavey', or 'cook-general'. In the twentiethcentury, more lower-middle-class families were keeping servants, and inevitably there was some fluidity between servant-keeping circles and those working as servants." "A London general" wrote to the Women's Industrial Council 1916 enquiry into domestic service that she hoped "at the end of this year to be in a position to keep a maid of my own." ${ }^{10}$ This simple statement epitomized the fears of many over the eroding boundaries of social class, and led to a complex of emotions which as tried to deal with the new proximities. As Homi Bhabha has written, "'all the affect, anxiety, disavowal comes not at the point at which differences can be binarized or polarized [but where] differences are ... very small."”11 Impersonations which seemed on the face of it to be motivated by a fascination with 'otherness' were in fact a means of dealing with social intimacy and proximity.

The fluidity and lack of boundaries was endlessly debated within the British 'servant problem' literature. In 1912, it was a straightforward assertion of Cassell's Household Guide that "the mistress is of higher mental culture than her servant," and thus could act as an authority figure. ${ }^{12}$ But numerous other writers on domestic affairs had already acknowledged the possibility that things were changing. One noted "We have advanced, so have our servants; and when they can beat us at sums and geography, stand too much on our level to be thought of merely as the servants, who are to be content with anything we may choose to give them and therefore must be treated in an entirely different manner to the old style." ${ }^{\prime 3}$

In this context, the dress of servants caused particular anxiety, since servants might be dressed in the outcast garments of their employers, and thus might be mistaken for them. Employers were aware of this problem. Margaret Powell recalls of her time in service in the 1930s, "You'd have thought that cast-off clothes might have found their way downstairs, but they didn't. They didn't care to give them to the servants because they wouldn't want you to wear them while you were living in their house..."14 Naming was also a source of concern. Numerous servants reported that on entering service, their names were changed, because their names were the same as one in the employer's family, or were 'too fancy'. ${ }^{15}$ Employers continually reiterated their fear that servants were socially indistinguishable from them, in education, dress and aspirations.

During these decades of great social pressure for the maintenance of social distinctions, there was intense interest in impersonating or changing places with servants. This had a long-standing cultural presence; Carolyn Steedman has noted the fantasy power of the "voracious eighteenth-century appetite for reading about servants as copycats." ${ }^{\prime 16}$ But for most Victorians, domestic service had been imagined as a particularly difficult realm within which to cross class barriers; 
Arthur Munby, a civil servant who had secretly married a servant Hannah Cullwick in 1873, reported in his diary a conversation with a servant-keeping woman concerning marriages between servants and masters: "She refused to believe that any such woman could by possibility be refined in nature or be companionable for a man of education. She knew [servants] by experience: their faces might be pretty and their manners modest, but within they were full of baseness and vulgarity." ${ }^{17}$ Servants might look similar to those of superior social standing, but were regarded as fundamentally different in character. Working people were persistently regarded by their 'superiors' as physically different. As George Orwell wrote, "Very early in life you acquired the idea that there was something subtly repulsive about a working-class body... the smell of their sweat, the very texture of their skins, were mysteriously different from yours". ${ }^{18}$ Servants epitomized these differences; their hands, gait, and body odour were particularly remarked upon. ${ }^{19}$ One 1896 household manual advised the employment of lady helps rather than working class servants because of their different physical presence in the home: "There is much less wear and tear of carpets and floorcloths by the feet of young ladies, as compared with those of ordinary housemaids." ${ }^{\prime 2}$ In 1911, an etiquette manual author wrote "I know that servants can be distinguished by the short abrupt steps they take." As Leonore Davidoff has pointed out, both authority and deference were marked by "silent body language" in domestic service relationships. ${ }^{22}$

As the most everyday and intimate realm in which individuals of different social classes confronted each other, domestic service was central to the ongoing enactment of class as a deeply embodied set of social relationships. Its discomforts and encounters were taken to stand in for much wider horizons-the 'spirit of the times' or social change in general. Transgressions within this domain were therefore particularly loaded with emotional and cultural meanings. Munby and Cullwick did not make their marriage public until after their deaths, though Munby was confident that Cullwick could pass at will between social roles. He commented in his diary, "is she not a servant during the day, and a lady in the evening? And fulfils either part so well, that for the time being she seems incapable of the others." ${ }^{\prime 23}$ Hannah Cullwick's occasional performances as a middle class lady, however, were uncomfortable and brief. She recognized it as a 'passing' which involved considerable effort and constraint on her part. After a few experiments with middle class dress for Cullwick, both parties were content that she should continue to work as a general or scullery maid, and maintained the rituals of class disparity, especially those surrounding the idea of pollution and dirt associated with domestic service. Cullwick commented on returning from her honeymoon where she had dressed as a 'lady'; "Here I am, very glad to get back. I've doffed all my best clothes and put my own on again-my dirty cotton frock and apron and my cap..." 24

Servants also impersonated their employers as a form of 'below stairs' satire and comedy, and enjoyed their class-crossing powers of being able to adopt 
different accents and mannerisms at will. Other servants, often menservants, took pleasure in adopting as their own the habits and mannerisms of their 'superiors'. Margaret Powell described a butler in the 1930s who "aligned himself with his Lordship". "When his Lordship went out to dinner Mr. Moffat went out to dinner, because in his mind's eye he saw what his Lordship was doing. When his Lordship was presented to noble personalities, Mr. Moffat was also presented to them. I could tell that because he told us things in detail that he couldn't possibly have known because he wasn't at the functions." ${ }^{25}$

Employers both desired and ridiculed such a servant, as Powell realized. Rosina Harrison, a ladies' maid in the 1930s, described a similar relationship between Lord Astor and his butler, Mr. Lee, who "liked and admired everything that he saw of Lord Astor and tried to emulate him either consciously or unconsciously." ${ }^{26}$ The author Samuel Butler and his valet, Albert Cathie, staged a similar relationship, which became somewhat sinister after Butler's death in 1902 when Cathie took on Butler's habits, adopted his clothes and "massive silver watch", sat at his desk and followed Butler's routines. For a commentator in the 1940s, this transformation made Cathie "a displaced man, a man cut off from a vital focal point in his own existence..." ${ }^{27}$ Most of the servants who in some sense changed places with their employers were not seen as able to pass without penalty in the way middle-class impersonators could. Instead they became comic or tragic figures, unable to subvert or performatively establish class boundaries.

There were, however, long-established opportunities for servants to 'reverse roles' by claiming cultural authority to write and publish. ${ }^{28}$ As literacy became more widespread from the 1860 s, there were enhanced possibilities for servants to read and comment on the 'servant problem' literature aimed primarily at mistresses. The influence of the women's movement was also felt, and empowered some servants to read and answer back in the pages of feminist periodicals. In the face of numerous diatribes from suffragist mistresses about their servants, one servant wrote to the suffragist paper The Common Cause, to remind its readers that "This servant agitation belongs to the feminist movement." ${ }^{29}$ Servants had long been described as silent spectators of the life of the upper and middle classes, but were increasingly offered new resources to become cultural and social commentators themselves, through their own participation in and consumption of mass media such as newspapers, music hall, cinema, and radio.

But despite these resources and sense of relative social flux, nowhere in the 'servant problem' literature were servants asked to change places mentally with their masters or mistresses, nor was it common for servants to effect this kind of reversal in real terms. Outraged statements of servants losing their "sense of place" and becoming "mistress of the situation" were widespread amongst the employing classes. ${ }^{30}$ But these were more rhetorical than real assertions of role reversal, and in the main, it was employers - and almost always mistresses - who might aspire to change places with their servants. 
Such experiments had not always been imaginable; a widely circulated pamphlet, titled Advice to Young Women on going to Service (1829), noted: "You would think it ridiculous to see your mistress dressed in a coloured apron and handkerchief with a coarse gown and coloured stockings such as would be proper for you to wear; and she would be wrong to dress so because we ought all to appear according to our different stations." ${ }^{31}$ But this advice (intended to regulate servants' dress) was superseded by instructions to mistresses in the twentieth century, for whom role reversal could be understood as, at the very least, a useful and possible thought experiment. One commentator suggested in 1914 that mistresses "might with great advantage put themselves in imagination in the domestic's place more often than they do." This "mental exercise" was to be "conscientiously executed for five minutes once a week". ${ }^{32}$

Mrs. Peel, a well known writer on domestic affairs, expanded on this idea in The Queen in 1915,

Let the house-mistress begin to think of herself turned servant. What kind of worker would she be? Or can she imagine her own daughter rising at 6.30 and working skilfully and pleasantly throughout the long day, content with a weekly evening out and an alternate Sunday? How does she like the idea of her friend Mrs Montmonrency Parker as a cook? Would she feel inclined to trust her children to nineteen-year-old Miss Buckingham Smith? Pursue the subject further. If she herself were obliged to become a servant, what are the conditions of labour to which she would most object? If she were taking her Gladys to see Mrs Robinson with a view to her becoming that lady's tweeny maid, how would the position strike her?

Despite her sensitivity to the double standards of Edwardian employers, Mrs. Peel displayed an untroubled confidence that as a mistress, she was qualified to "look at the profession of domestic service from the point of view of the servant." Like so many of her middle-class peers, she invoked "a careless sense of universality" that enabled her to speak for all women and inhabit all viewpoints, a confidence that also sustained those who impersonated servants. ${ }^{33}$

\section{Slumming?}

For a few middle-class employers, an abstract thought experiment was not enough. Instead, they took on servants' uniform and tasks in person. Nineteenth-century traditions of social investigation, philanthropic and journalistic, may have stimulated this desire. Seeking rational solutions to the 'social question', influential investigations into the lives of 'the other half' were undertaken by individuals such as Charles Booth, Clara Collett, Stephen Reynolds, and Seebohm Rowntree. These 
investigators rarely sought to impersonate the subjects of their inquiries; instead, they saw themselves as impartial observers, who interviewed, and acted as "an intermediary between the classes, ... to explain to one half how the other half lived." ${ }^{34}$ Nonetheless, their work sometimes shaded into impersonation. Booth, who took up lodgings in London's East End, claimed to have deceived his landlords that he "was not who he was". He felt that he had genuinely experienced life as a working man. ${ }^{35} \mathrm{~A}$ new sense emerged from his notebooks, that one can "find out for oneself what it was like to be poor." 36

Booth's attempts at impersonation were however limited; like most other male middle-class observers of working-class life, he tended to observe without comment on his own class status and presence. This was also the case with those attempting to cross class barriers through the settlement movement. Nonetheless, it became highly fashionable to live amongst the poor as 'one of them'. The life of a vagrant might be imitated by taking up the newly fashionable camping or hiking, or even as a 'complete participant' in a burgeoning tradition of social impersonation. ${ }^{37}$

Settlement work and slum visiting were also given currency by the investigative or 'stunt' journalism of the mid to late nineteenth-century which fed into practices and texts of impersonation. This became popular in America and Britain, inspiring a series of impersonations that Seth Koven has argued were inaugurated in Britain by James Greenwood's notorious "A Night in a Workhouse", published in the Pall Mall Gazette in $1866 .{ }^{38}$ This style of reporting was obsessed with 'how the other half live'. "A Night" had a wide circulation, spanning both 'high' and 'low' audiences, in pamphlet and dramatic form, and was widely imitated in Britain and the United States in the second half of the nineteenth century. ${ }^{39}$ The American writer Jack London in his investigation of London's East End, The People of the Abyss (1903), explained his motives: "I wish to know how these people are living there, and why they are living there, and what they are living for. In short, I am going to live there myself." 40 London, like many of his contemporaries, regarded himself as perfectly accepted by the class he sought to impersonate, simply by virtue of his clothes.

\footnotetext{
No sooner was I out on the street [in working man's clothes] than I was impressed by the difference in status effected by my clothes. All servility vanished from the demeanour of the common people with whom I came in contact. Presto! in the twinkling of an eye, so to speak, I had become one of them. ${ }^{41}$
}

Journalists such as Henry Mayhew or W. T. Stead aimed at sensational and entertaining copy, but also had serious reformist goals. The journalistic tradition, however, tended to stress the drama of role reversals in a fashion that placed them close to the carnivalesque or comic role reversals that abounded in popular 
culture. Role reversals of various kinds regularly surfaced in music hall, musical comedy, mass periodicals, and later in cinema and radio. Cross-class (and crossrace, -generation and -gender) impersonations were prevalent as comic sketches within the late Victorian and Edwardian entertainment industry. ${ }^{42}$ Narratives found within the popular press sensationalized social investigation to provide good copy for the press; others wrote within the familiar comic genre of domestic service humour.

\section{Women as role reversers}

How available were these genres, comic or otherwise, to women? Seth Koven describes how, following Greenwood's success, the workhouse reformer J.H. Stallard commissioned an investigation of the female casual wards in 1866. But he claimed that a 'true lady' could never pass for a tramp: "No lady could be found to imitate the act, and if the attempt were made, no rags would disguise her character, no acting would conceal her disgust." ${ }^{43}$ Instead, he hired a destitute widow, Ellen Stanley, to report for him without having to perform any reversals, which remained a male preserve. The American journalist Nellie Bly, however, had undertaken undercover work in the United States to investigate child and sweated labour from 1885, and the participation of women in this style of journalism, as well as in philanthropic work that required impersonations, became well established on both sides of the Atlantic. Towards the end of the nineteenth century, women had become more mobile figures, accessing new spaces of investigation and pleasure. New urban public spaces became accessible for women, ranging from the music hall to the department store. ${ }^{44}$ For elite women, urban slums and sweatshops also became locations they could enter as curious reformers. Beatrice Potter disguised herself as a Jewish "trouser-hand" in 1888, and claimed that this gave her investigation into sweated labour extra validity. She claimed both invisibility and empathy as the positive products of her disguise, and in similar terms to Jack London, Potter declared herself to be "surprised at the complete way they have adopted me as one of their class." ${ }^{45}$

Elizabeth Banks brought American techniques of investigative journalism to Britain in the 1890 s in her undercover investigations of women's work. She inspired intense public interest, particularly through her impersonation of a housemaid, but was accused of 'unwomanly' behaviour. ${ }^{46}$ Nonetheless, others followed her. The idea of women undertaking such investigations quickly became parodied in fiction; George Sims published in 1902 a short story in which a mistress realizes that her former parlourmaid was an American journalist. ${ }^{47}$ In 1904, Mary Higgs undertook Five Days and Five Nights as a Tramp, followed by her 1906, parallel to Jack London's study, titled Glimpses Into the Abyss. Higgs toured the female casual wards and lodging houses of Lancashire, disguised as a tramp. She described her impersonation as an "ordeal", necessary because other methods of investigation proved useless. ${ }^{48}$ With a more overtly political intention, Lady Constance Lytton 
famously disguised herself as a lowly suffragette 'Jane Wharton' in 1909 in order to expose the class hypocrisy involved in prison treatment. ${ }^{49}$ Female impersonations, then, were perfectly possible, and became a sensational feature in Edwardian reform and entertainment texts.

Concerns with poverty and social otherness continued to be a key motive for class crossing in the interwar decades. Ada (Mrs. Cecil) Chesterton disguised herself as one of the poor and wrote two sensational class-crossing narratives, In Darkest London (1926) and I Lived in a Slum (1936). ${ }^{50}$ She assured her readers that as a shabbily dressed woman she could easily "melt into the landscape of the underworld and become so absorbed by the atmosphere that I escape attention..." ${ }^{51}$ Chesterton noted how many former servants she found who had taken charring work to survive, which she herself did as well. ${ }^{52}$ Celia Fremlin and Monica Dickens impersonated domestic servants in the late 1930s, and numerous newspaper features of the Edwardian and interwar period recounted impersonations of servants.

In fiction and in reality, domestic service was a key point at which social transgression took place, and one seen as especially amenable to middle-class women's interventions. For much of the twentieth century, while many aspects of women's lives and work were investigated, domestic service was almost compulsively returned to. Service was understood as a social institution that both exacerbated, and yet might solve, social problems of (feminized) poverty. The flourishing literature on investigating poverty did not just parallel that on domestic service-the female poor and fallen were understood to be largely composed of former or casually-employed domestic servants, and service or charring was to provide a respectable route out of destitution. The links between poverty, prostitution, and domestic service were powerful, and it is no surprise that similar methods were used to investigate these domains. As Mary Higgs wrote of her investigation into homeless women, they 'might be servants out of place. ${ }^{53}$

Nonetheless, class-crossing impersonations of servants were quite different from 'slumming'; it sheds little light to see these kinds of narratives as inaugurated by the 1866 'A Night in a Workhouse'. While informed by the practices and scripts of slumming, domestic servant impersonations were deeply shaped by their location within the 'servant problem' literature that had been so prominent in the nineteenth-century press, and retained just as high a profile in the twentieth century. 'The servant problem' generated its own meanings, metaphors, and concerns that were more about middle-class identities and the encounters between classes than problems of poverty and social otherness. And additionally, many narratives were shaped by their location with the commercial world of entertainment; servants were stock component of comedy for the first half of the twentieth century, and were depicted as funny in a wide variety of places. Elizabeth Banks' write-up of her impersonation of a housemaid was intended to be bright and entertaining, much to the irritation of reforming mistresses who had expected a more philan- 
thropic motive. ${ }^{54}$ Monica Dickens's 1939 One Pair of Hands was read by reviewers as a comic, vivacious, adventurous book, despite Dickens own comment that it was a 'most depressing period of my life.'

Elizabeth Banks, impersonator of a housemaid in 1894, has been seen as a premier 'slumming' journalist, writing extensively on the work of poor women. Banks's career was based on her insights as an American outsider offering critical social commentary on English class society. ${ }^{55}$ And like Jack London, Banks regarded adopting the clothes and conditions of a working woman as a 'presto' transformation that enabled a new social class to be taken up at will. She started her British career, however, with an interest not in poverty and the 'social question', but with the 'servant question'. She took the techniques of social investigation to the upper-middle class servant-keeping home, in pursuit not of poverty but class antagonism evidenced in the servant problem. Tellingly, Banks devoted many pages of her 1902 autobiography to her domestic service impersonation, but said of her experiences as a flower girl and crossing sweeper, "They did not take up any very serious social or moral problems." ${ }^{56}$ She clearly distanced herself from slumming and its focus on poverty.

Banks caused a sensation in London when she published her account of life as a domestic servant, 'In Cap and Apron', in The Weekly Sun in 1893, and later as a collection titled Campaigns of Curiosity. Her account of domestic service hovered uneasily between entertainment and a reformist agenda. Her light tone and choice of an inexpensive and popular paper for publication distinguished her work from the philanthropic tradition that motivated forays into casual wards and slums. ${ }^{57}$ Banks advertised herself in a newspaper as a "refined and educated young woman, obliged to earn her own living," and was swamped by 159 replies to her advertisement. Of these, however, few offered conditions she could accept. Many offered care of children, which she was not willing to accept. She also refused to accept posts, which required her to cut her fringe, or share a bed (her curiosity did not stretch that far). With these limitations, Banks eventually obtained two posts, and held each for a week. Her two employers provided a striking contrast, enabling Banks to illustrate what a good and bad employer can be. The bad employer preached biblical texts of duty and station to her servants, but through thoughtlessness and laziness created vast amounts of unnecessary labour. Candles, for example, were used throughout the house, although gas lamps were installed; goods lifts were not used between floors; none of the family had latchkeys, and kept the maid waiting on them until the early hours. The second employer, by contrast, offered labour-saving devices, provided all members of the household with the same food and cutlery, used only gas fires, and contracted out some of the dirty work (steps, boots and knives).

Banks was outraged by the conditions some worked under, and called for reforms, including days off, and compulsory characters (references) provided by both servant and employer. But she was more interested in the attitudes and sub- 
jectivities of mistresses and servants than in labour conditions. Though she felt accepted as 'one of their own kind' by other servants, she was appalled at what she saw as their laziness, extravagance, and desire to change jobs without reason. She noted that the cook and housemaid were "continually on the defensive, and seemed to believe that mistress and servant must necessarily look upon each other as enemies." 58 Of her own interactions with servants, Banks wrote: "I was discouraged with trying to instil right principles of action into Alice's and Sarah's minds ... The motto which they seemed to think was the proper one between kitchen and drawing-room was 'War to the Knife." Banks' need to instruct her fellow servants indicates little sense of shared 'station', and she adopted a thoroughly condescending tone towards their attempts to enlighten her as to how the job should be done. When her fellow maid tried to give Banks hints on how to avoid excessive labour, she rejected this as not appearing "nice". ${ }^{9}$ She concluded that there were as many ill-treated mistresses as servants in London. This 'role reversal', then, was pretty limited, given Banks' inability to understand the reasons why servants would want to build up a space for the assertion of their own dignity and humanity, in subverting the orders of their employers. Nor did she acknowledge the practical necessity of 'labour saving' tricks, for those whose working day could never accommodate all the demands being made on them. Overall, her tenuous role reversal did not involve putting herself psychologically into the place of the servant. Her narrative did, however, turn on a sense of profound transgression; on meeting an acquaintance while in service, she was deeply embarrassed. She wrote of her "constant dread in which I lived of being 'found out'."60

The two decades which followed Banks's 1894 impersonation saw a rise in absolute numbers of servants, though the start of a relative decline in their numbers. Servant-keeping was spreading down the social scale, though there was intense hostility towards the keeping of servants by clerks, teachers and minor professionals in the suburbs. It was a period of flux and uncertainty, with a deep fascination displayed in cultural depictions of class crossing, through literary characters such as Eliza Doolittle (1914) or the 'admirable' Crichton (1902). ${ }^{61}$ It is a period in which the possibility of young women refusing to take service jobs first became widely prophesied or experienced; young women began to have other options in light industry, clerical or sales employment, though domestic service continued to be their largest employer. The servant problem began to centre on the discomfort of having to acknowledge and refashion egalitarian principles within servant-keeping homes, which increasingly contained just one or two servants and therefore had fewer intermediary figures such as housekeepers to cushion the interactions between mistress and her "cook-general". ${ }^{62}$

There were more opportunities for extended periods of role reversal, with less fear of the crossing of social boundaries, during the First World War. As so often in Britain, comic anecdotes about servants were used to indicate the wider social changes brought by the war. Ursula Bloom, brought up in a servant-keep- 
ing family, recalled that their housemaid married a major during the war. This class-crossing "surprised us very much, for it showed the new spirit, and I meditated, did I now have to call Alice 'ma'am'?"'3 Bloom joined the Voluntary Aid Detachment (VAD) during the war, and became a parlourmaid within a convalescent home. "I myself became a servant", she declared in dramatic terms. She concluded that as a VAD parlourmaid she worked much harder than her own servants, and lost sympathy with their claims to be overworked. ${ }^{64}$ But in general, most mistresses concluded that servants were asked to work extremely hard. Violet Butler of the Women's Industrial Council noted, "A considerable number of the servant-keeping classes have in the last eighteen months done strenuous manual work in hospitals and canteens; they may have revised their previous views as to domestic service." ${ }^{65}$ A letter to The Queen in 1915 offered a role reversal tale cut down to the bare bones, but with the appropriate moral sentiments of pride, a fall, and a new understanding.

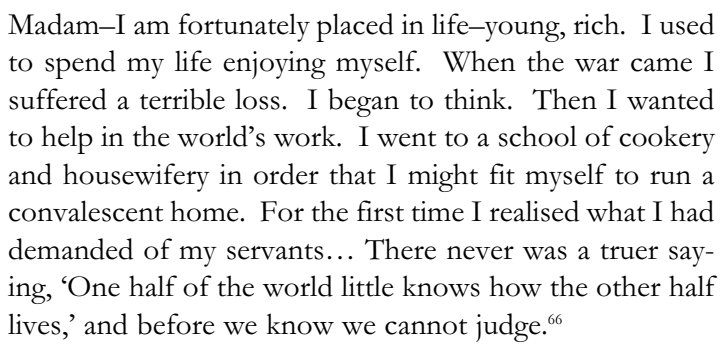

Post-war role reversals became less closely modelled on the sensational journalism of late-Victorian and Edwardian times. Violet Firth, a theosophist and psychologist, argued against a 'slumming' approach: 'The point of view of one who really 'takes a job' in order to earn a living is quite different from that of one who, in more or less of a disguise, penetrates into working-class conditions in order to see 'how the poor live.' ... The adventurous journalist exploring darkest England in disguise cannot interpret the soul of the worker." ${ }^{67}$ Firth recommended more than a brief moment of disguise, in her study inspired by her war-work, The Psychology of the Servant Problem. She wrote accusingly "The employing classes... are so habituated to the presence of a being from another sphere who is credited with a blissful freedom from human feelings that it is a shock to them to find human nature akin to their own concealed by a servant's apron. ... If they would try the experiment of working for a time in someone else's home they would know the reason [why girls will not enter service]." ${ }^{68}$ However, she could only make a rather dubious claim to being a role reverser, not having worked as a domestic but as a "lady gardener" during World War I. Nonetheless, to her mind, being "virtually in the position of a servant under private employers" during the war years gave her the personal experience of "knowing the minds and feelings of the girls I met 
during those three years in a way that I could never have done had I descended upon them from an above-stairs Olympus..." ${ }^{99}$ As a gardener, she had found that her "interests were identical with those of the servants," and she felt personally the pressures of their positions. "To be a servant" was not to undertake her actual work, but simply to be a dependent worker within a private household.

Nonetheless, as a trained psychologist, Firth saw herself as epistemically privileged, in understanding both the mind of the servant and the employer, and in bringing scientific observation to bear during her time in which she 'passed' as a servant. Drawing on what was becoming an established discourse of anti-suburbanism within servant problem texts, Firth directed her criticism towards the middle classes, who were responsible for servant antagonism by taking on servants they could not afford, and trying to imitate wealthy aristocrats: "the suburban villa is a miniature mansion, and the mistress of it endeavours, with the help of some little ignorant girl, to have the same ritual of front door and late dinner that is carried out with a butler and footmen." Af After what she saw as the "end of epoch" marked by the Great War, Firth optimistically proposed a simplification of life for the middle classes, with co-operation and communal living to make service redundant.

Like Elizabeth Banks's account of service, Firth's work displayed a deep lack of insight_-despite her assertion that she "made common cause with the kitchen", she could not see the injustice of the system as anything more extreme than the experiences of school days — she advised that "Mistresses will get many insights into the viewpoint of their servants if they will look back upon their own school days and remember what manner of things struck them as unfair and raised their resentment." ${ }^{71}$ Following these directions, role reversal was easy-one's own experiences of childhood powerlessness gave sufficient insight, and servants were firmly metaphorically linked to children.

In the 1920s, the genre of role reversal had developed away from the sometimes crude polarities of slumming or stunt journalism, and the 'servant problem' literature that framed it also changed. Firth's 1925 account was written with the wartime and immediate post-war experiences in mind, and this was a particularly potent period of discontent with domestic service, and of intense middleclass anxiety as to whether women would willingly return to domestic service. The fear that they would not generated three large-scale inquiries in a decade: the 1916 report of the Women's Industrial Council, the 1919 Ministry of Reconstruction report, and the 1923 report to the Minister of Labour. Each report generated widespread media coverage on the topic of service, and all warned of the trend towards a balkanization of social class, and failure on the part of servants' employers to understand "the spirit of the age". ${ }^{72}$ Nonetheless, there was a widespread assumption that private domestic service would continue, perhaps reworked as a contribution to national efficiency, but substantively along pre-war lines. ${ }^{73}$ As one writer put it, "Domestic service requires a re-statement which will chiefly and 
among other things re-establish its goodness as of infinite worth, not only to the individual, nor to the particular family in question, but to the nation as a whole." 74 The 1923 government report spoke of service as "the highest privilege of life." 75

Conversely, numerous writers wrote of their sense of epochal change; as J.B. Priestley put it in 1927, domestic service had become "as obsolete as the horse." " Others proposed extreme measures, such as compulsory training in domestic work for all women, to halt the three perceived 'great declines' of the 1920 s - the birth rate, marriage, and domestic service. 'Changing places' within domestic service, however, continued to make good newspaper copy in the years after the war. Class relations were just as salient and fascinating in interwar Britain as they had been for Edwardians, and discussions of domestic service suggest that it still epitomized social distinctions. The Daily Chronicle, a liberal penny daily, ran a number of articles about the 'Countess de Armil', who in 1924 "took a post as a parlour-maid in order to learn the truth about domestic service first hand." ${ }_{77}$ As was typical of the more sensationalist role reversers, her post only lasted a fortnight. Her recommendations were quite broad (a union and a pension scheme for all servants), but the emphasis of the Daily Chronicle was on the possibility of reformed class relationships, writing optimistically of the Countess's own kindness to her servants, and the possibility of personal relations of paternalistic good nature.

At the end of the 1920s, the Labour Party published a pamphlet titled "What's Wrong with Domestic Service?". They distributed 15,000 copies to women's groups, servants, employers and Labour Party organizations. The party called for a national inquiry into the unpopularity of service, and sparked off yet another intense debate in the newspapers. Margaret Bondfield, the Minister of Labour, was widely reported as claiming domestic service as an honourable occupation. ${ }^{78}$ "Honour" certainly was central to the debates-the servant problem emerged starkly in interwar accounts, as centring on the social humiliations required of servants, and their cultural representations.

In 1930, the Manchester Guardian published a letter describing a role reversal, though the trappings of disguise and transgression were falling away. "E.V.P.", an office worker, wrote of her initial agreement with Margaret Bondfield, and her experimental three-month post as a cook-general, to test out the profession for herself. ${ }^{79}$ Her duties were light, and she worked comparatively short hours. Nonetheless, she found the social relations of service intolerableand unlike most other role reversers, she was strongly pessimistic for the future of domestic service The "growing sense of inferiority" that came from being treated as a social outcast made the position unbearable. The writer noted that "some of the [friends of the mistress] were girls employed in similar positions to that I had held before I donned the cap and apron of domesticity," and she resented their disdain for her company. The snobberies of social class, then, emerged as the bedrock of discontent with domestic service, made particularly acute by the rela- 
tive lack of social distance between interwar servant and employer. A recasting by "E.V.P." of cap and apron as symbols of domesticity rather than servility and drudgery hints at the increasing prominence of the identity of the housewife in the interwar years, an identity which crossed class boundaries and offered an alternative basis for feminine subjectivity. ${ }^{80}$ The possibility of being a housewife also made being a mistress a more complex affair, and the impersonators of servants in the 1930s seemed defensive, and concerned to bolster their own identities as domestically capable, despite being servant-keepers.

The feminist writer Ray Strachey characterized the 1930s as a period in which domestic service was more popular than in the 1920s, and had "gained in profitableness and in the leisure time offered." ${ }^{81}$ Strachey was therefore confident that domestic service could be rejuvenated and sustained in British society. It was in reality the economic downturn and the coercive nature of the unemployment benefits system that returned some women to service, which was still employing 24 percent of the entire female working population in 1939, with a much higher proportion in some regions.

Despite the upturn in numbers and Bondfield's attempt to designate it as "honourable", domestic service continued to be a realm of controversy in the years before World War II. The obsessive discussion of 'servant problems' in the media indicate its role in negotiating the intense pressures between the shift to a more egalitarian democracy and the continuing resonance of ideas of social status and hierarchy. An extended account of 'passing' as a domestic servant was offered by Monica Dickens in One Pair of Hands, published in 1939. Though Dickens was not a political radical, her work may have been influenced by a mode prevalent in the late 1930s, of politically committed social realism and documentary, in the work of Mass Observation, Walter Greenwood, George Orwell, and so on. ${ }^{82}$ This genre resonated with the preceding tradition of slumming journalism, though its practitioners in the 1930s were more influenced by an attempt to portray the 'ordinary' aspects of (working-class) British life, rather than the social otherness of slums and the poor. George Orwell felt that through role reversal, class differences might finally evaporate: "To get rid of class-distinctions you have got to start by understanding how one class appears when seen through the eyes of another." 83 Monica Dickens also voiced a desire to break down "the entire regime of Class in England" through her impersonation of a general servant. ${ }^{84}$

After a privileged upper-class upbringing, Monica Dickens 'whimsically' persisted for a year and half with a string of short-term daily and live-in domestic posts as a cook, cook-general, scullery maid, laundry maid, and housemaid. While working as a daily cook-general, Dickens remained served by her own household servants, who had to accommodate her new early-rising hours. Her experience of role reversal was thus tempered by her own continuing and unremarked reliance on servants-but seemed to be a far deeper identity shift than that of the didactic Elizabeth Banks, or the scientific observer Violet Firth. She took the jobs for 
longer periods, including living-in posts, and seemed to be more than simply curious about them, but sought to find dignity in domestic work. Nonetheless, Dickens acknowledged herself to be, as so many servants were accused, slovenly and incompetent. With her first mistress, "life was a wordless and unacknowledged battle of wits between us, with her keeping a sharp look-out for signs of dirt and neglect, and me trying to disguise my slovenliness by subterfuge." ${ }^{85}$ But she could not wholly adopt the mentality of a servant; the complaints and gossip amongst servants about 'them upstairs' continued to make Dickens feel uneasy, and she was wholly unable to get on with the working-class men (tradesmen and workmen) at her jobs, who recognized and lampooned her class status.

The exhaustion and continual exploitation of a single handed servant was emphasized in her account-even where her employers were considerate. Some employers treated her as one of the family, ate at the same table, and shared their woes with her. Most employers, however, were exploitative, still unwilling to use labour-saving devices, and treated her as a sub-human: "a maid makes a good defenceless listener for people who want to talk about themselves and not be answered back." "\$6 She chronicled the sexual advances that servants were vulnerable to, and lost a job over the unsolicited attentions of one employer's boyfriend. Despite her commitment to breaking down social class barriers, Dickens could not tell her friends in society what her occupation was, and when she met an 'old flame' at a servants' ball, she was (as Elizabeth Banks had been under similar circumstances) extremely disconcerted, and eventually forced to leave that job.

As a servant, Dickens shared some of the experiences of her peers-she shifted her job rapidly, found it hard to get references, largely chose the least troublesome way of carrying out her work, and hid her breakages. But she did not seem to realize that what for her were just inconveniences (not getting a reference after being blackmailed over alleged sexual misconduct) would have far more profound consequences for a working class woman. Having been extremely cagey and unconvincing about her motives for engaging in domestic service, she acknowledged towards the end that it had been in part "curiosity ... or interest in seeing Life in the Raw. I had found out all I wanted to know about kitchen affairs, and a great deal too much about the squalor attached thereto." ${ }^{87}$ It was easy for her to exit when exhaustion became too much. Drawing on the authority of impersonation, she became a public speaker on domestic service, arguing in reformist terms for more training and respect for domestic servants.

A similar undertaking of role reversal was published as The Seven Chars of Chelsea in 1940 by Celia Fremlin, a self-acknowledged 'arm-chair socialist' who wanted to understand class society. ${ }^{88}$ Fremlin's late 1930 s posts as a live-in scullery maid, a boarding house maid, and a charwoman in a public hospital, suggest the growing diversity of domestic service, as more and more employees went into institutional service. Her experience of a traditional living-in post in a private household, working as a scullery maid to an upper-class lady, was not positive. In 
this job, despite the high salary and very light duties, Fremlin likened her role to that of a contented poodle always on a lead. The house was like a 'model prison', in which servants performed a series of empty duties. In contrast, Fremlin's service as a boarding house maid was more rewarding, despite the squalor and hard work, because it was in her opinion a realm of classless interaction. All participants (servants, manageress, lodgers) were treated as equals, and this gave a vitality and freedom to daily life that could not be matched by the 'good' live-in job she had held previously. In similar terms, Fremlin's job in a hospital was marked by hard work, and some arbitrary traditions that made the work harder than it needed to be. But in general, the work of a charwoman was described as full of vitality, humour and resistance to their treatment as "dopey" individuals. ${ }^{89}$ Institutional domestic service was thus accepted by her as a realm of working class solidarity, and relative social freedom.

The solution to the servant question offered by these role reversers generally centred, like all the government investigations into domestic service, on training and specific reform of micro-conditions (such as providing sitting rooms for servants to entertain their 'followers'). Monica Dickens advised training for domestic service, teaching its skills as a science; this training was to be provided to servants and mistresses, who were both lacking 'domestic common sense'. As for many contemporaries, her solution was understood as parallel to the professionalisation of hospital nurses and children's nannies-to be achieved without state regulation of wages and conditions, but through training and accreditation.

\section{Post World War Two reversals}

The final examples of role reversals occupy quite a different place-indeed, though they have the same narrative structure as earlier examples, they are barely of the same genre. The act of impersonation became less central, and 'reversal' less key to the narrative. The first account was written by an Oxford undergraduate, Mary Cosh, who worked as a cleaner and later a cook in a block of service flats during one summer vacation in 1949, and wrote of her experiences in The Spectator. She described the toil, monotony, and the idiosyncrasies of her clients-but lacked a sense that she was radically shifting to a whole new sphere of life. Cosh still subscribed to the fantasy that she was "looking through the eyes" of the Irish housemaid she worked with. "I began to form an outlook on a household which is, I suppose, peculiar to 'below stairs,' unsuspected by those on the other side..." But this simply amounted to a humorous objectification of her clients, viewing them as 'early riser' or 'untidy' rather than as complete human beings. She did not describe any particular class antagonism, or distinctiveness of domestic service as a 'problematic' profession. Instead, she admitted her admiration for a wide range of 'service-givers': "hotel and restaurant chefs and waiters, dustmen, shopkeepers, milk roundsmen"' . Personal service had become a much wider category, and the 'servant' problem' had become transformed into the 'service problem'-the 
thankless and invisible nature of the services that make modern cities liveable. Service no longer seemed to have the connotations of servitude and servility, nor was it such a gendered entity; Cosh notably included men in her list of servicegivers.

A similar narrative was offered by a professional cook in 1950. Elizabeth Jordan introduced herself as a mother and housewife in the mid 1940s, who decided to go out as a daily cook, paid for by the evening, in order to pay for her own charwoman and governess. There is little sense of class distinction in her narrative, except for her unwillingness to wear the white apron traditional to cooks, and to call her employers 'sir'. Indeed, because she did not wear the white apron, she was mistaken as her employer's girlfriend by guests. Unlike Banks and Dickens, she did not record as a dramatic incident the meeting of acquaintances while working as a servant - in fact, it was in many cases her acquaintances and friends that employed her. She noted, without comment, her own employment of a live-in housekeeper and nanny, and did not see a 'servant problem' to be solved in British society.

Class distinctions emerged in Jordan's account not between herself as an employer of servants and her fellow servants, but in her interactions with fellow trainee cooks at a school of cookery. She undertook training at the school in order to command higher wages, but recognized that most of the participants were debutantes, around whose needs the school was organized. It was thus the split between middle-class and upper-class that was foregrounded, and Jordan was comfortable with the idea of middle-class working women taking on traditionally working-class tasks. Middle-class women had come to define themselves as 'ordinary' and 'hard-working', distinct from frivolous and undomesticated upper-class women. Their identity could be merged with that of working-class women, united by domestic tasks that were invested with a new patina of creativity and satisfaction. Jordan regarded domestic service as a good occupation because it was well-paid, creative, and work was always plentiful. Her account derived its interests from the humiliations and complex situations a domestic servant had to negotiate, but in the main, these humiliations were not ones of social status and class. ${ }^{92}$

\section{Motives}

What can be said of the motives for these experiments with impersonating servants? There were complex psychic and social needs, as well as motives of commercial gain. It may be inevitable that in periods where there is a great deal of social anxiety about boundaries, there is a corresponding fantasy about boundarycrossing. Domestic service, like the world of the very poor, seems to have prompted fantasies about transgression and impersonation, perhaps motivated by the sense that these 'social others' had become threatening and insubordinate as well as fascinating. ${ }^{93}$ There was every reason for role reversals to be undertaken in this age of decreasing social distance between mistress and servant, fuelled by an 
intense public fascination with how servants and mistresses might relate to each other.

Many impersonators mention their desire to improve conditions, though those investigating domestic service were often doing so for self-serving reasons, desiring to perpetuate the system that enabled them to be served. Some may also have been motivated by a fantasy of 'passing' and of vicariously accessing the freedoms of the workingclass. Deborah Nord has written of the motive of shedding inhibitions through class-crossing disguise. There was clearly a fantasy of horizontal masculine comradeship and naturalness at play in Jack London's account of impersonation: "The man in corduroy and dirty neckerchief no longer addressed me as 'sir' or 'governor.' It was 'mate,' now...” al liberation, the possibility of re-imagining the self, and releasing new aspects of the personality. Beatrice Potter experienced an imagined working-class sexual freedom through her use of disguise. ${ }^{95}$

Seth Koven has stressed this often submerged erotic motive for impersonations and investigations; the transgression of social boundaries was eroticized. ${ }^{96}$ There was an attraction to the impersonation of servants that combined elements of erotic fascination/repulsion with a sense of comfort and consolation. This emerges most clearly in childhood memories of servants, with their stress on the comforting yet polluted smell of servants, and their central role as gatekeepers to a world of working-class freedoms. Children were well-versed in the role reversals of children's literature, and highly aware of the meanings invested in body language. They staged their own impersonations of servants; Jenifer Wayne wrote of her 1920s childhood:

I did try to copy Lucy on purpose. Her hands were very red, from washing and working, and she had a way of going about the kitchen with one hanging loose from the wrist, at chest-level. I wished my hands were red; it would have made me looked hard-worked and Cinderella-like; but the next best thing was to hang one limp, like Lucy. "What are you doing that for?" they said, and I had to put it down and keep my dreams of drudgery to myself. ${ }^{97}$

Jenifer's impersonation of Lucy went with a fascination with the 'forbidden and unattainable' world of servants and their families. She wanted Lucy to be on her knees, at her command in the safe middle class home. But she also longed for Lucy to reveal to her the glamorous, low, common, and dirty world of the Deptford slums, which seemed to be scented with 'Lilies of the Valley' perfume. Her impersonation was motivated by this emotional complex of envy, fascination and repulsion.

For adults, there were practical reasons for impersonating a servant rather than another kind of working woman. Dressing up as a servant provided 
an entrée to a relatively anonymous labour market, with a high turnover and strong demand for labour, with little training expected. It was an easy way to 'become' a working class woman. Some mistresses sought to prove that domestic work was simple and undemanding; others looked for psychological insights to how two classes might live together in increasingly informal and spatially desegregated households. It may also have been imagined that all women were somehow united across class lines by their skills in domestic work, and that it was therefore relatively easy for middleclass women to take up this occupation without comment. In doing so, the main motive seems to have been to investigate, validate and stabilize their own identities as mistresses.

\section{Caste and Class}

It may have been the limitations of languages of class in describing the relationships of domestic service that motivated this attention to 'mistresshood'. Narratives of impersonation are rich sources for the shifting languages available to talk about social difference-languages of caste, status and class_-and the way in which these interacted with gender. Such languages have never, of course, been transparent in their meaning or application. Elizabeth Banks and Violet Firth both hesitated between referring to social distinctions as 'class', or 'caste', and make clear the viability of alternatives to 'class' in the early twentieth century when discussing social hierarchies. Caste was frequently preferred, as it implied a largely subjective and imagined set of distinctions that were understood in the early twentieth-century to plague the working classes more than their 'social superiors'. In naming the servant problem as one of caste, it was implied that servants suffered an unaccountable loss of status amongst their own kind; training, certificates, uniforms, and professionalization were proposed as the chief solutions to this, without needing to change the behaviour of the servant-keeping classes or the working conditions they offered.

'Class' was however an alternative framework, and was tentatively used to imply a more objective sense of genuinely opposed economic interests. It carried uncomfortable imagery of unions and unrest which were not easily applied to that ambiguous workplace, the bourgeois home. When Violet Firth did write of class, she portrayed it as a barrier to national unity. ${ }^{98}$ It is revealing of her difficulty in talking about class that where she acknowledged class to be at play, she slipped from her habitual concern with female servants and mistresses, to a sudden concern with men. As she put it, “...in the case of a class distinction, the relationship is between man and man, and the inferiority is of manhood." It is clear that the language of class was gendered, referring primarily to the relationships of men within the landscape of 'the nation'. Nonetheless, the cross-class relationships between women were sometimes seen as even more antagonistic and problematic than those of men. Mistresses were castigated in newspapers and periodicals for having created 'the servant problem' through their snobbery and inability to relate 
to working-class women. ${ }^{99}$ Mrs. Peel wrote furiously in 1921 "Today we pay dearly for the reign of stupidity, for it is not the war of 1914 which as brought about the servant problem; it is the result of the long slow fight of the working people to gain such conditions as appeal to them, and of the obstinate effort of stupid women to stand in the way of progress." 100 'The 'natural' comradeship between men perceived by Jack London was not always imagined to be available to women. Gender, then, was both a distinction that transcended or eclipsed class, and yet also a staple marker of class. It is clear that languages of class in these narratives (which gradually supplanted caste) were being reworked, as they were produced in the servant-keeping home.

For Elizabeth Banks and Violet Firth, it was only going to be possible to employ one class of servants in the future, if intense antagonism was to be avoided. This did not mean a class-less society, but rather a more segregated one. Servant-keeping households should only employ servants who came from a similar class background to their employers-particularly, the genteel, poor, idle middle class girls who Banks regarded as leading "perfectly useless lives". ${ }^{101}$ Firth also regarded these girls as 'superfluous', and so ideal for domestic service. She pointed out that such girls could look for marriage partners from within their domestic workplace, in the "sons of the house or visitors," 102 and thus would avoid the sense of personal life isolation that made service so unattractive for working class girls. These authors proposed to abolish the concept of master and mistress, and have only 'employers' and their 'house employees' or assistants, who were to be social and intellectual equals. But the overall assumption was that class would remain a powerful force within society, so powerful that its boundaries could not be crossed.

Those influenced by the more radical social realist traditions of the 1930s, however, came to see the raison d'être of their investigation to be a repudiation of class. Monica Dickens for example, noted that class consciousness was "demodé, old-fashioned, feudal-we all know that." responsibility of each to try to break it down. But the more politically committed Fremlin was less optimistic. George Orwell had recently described class as "the plate-glass pane of an aquarium; ... so easy to pretend that it isn't there, and so impossible to get through it." Echoing him, Fremlin described class distinctions as "thin and clear as glass, but impenetrable," and as deep as the division between "civilised" and "uncivilised" nations. ${ }^{104}$ The servant problem interested her largely as an illustration of the 'bedrock of class society' that underlay all social interactions in Britain. Despite her 'panes of glass' metaphor, she felt that this 'bedrock' was beginning to crumble. Fremlin described as particularly problematic the performance of deference and authority (as markers of social class) when the (lowermiddleclass) mistress was "uncertain about her social position." 105 In describing an interview for a post in a small suburban house, she perceived that the script of class distinctions had broken down-it was no longer clear who should answer the 
door, who should precede who upon entering, what forms of greeting and farewell should be used. With a sharp eye to the micro-level of class distinctions, Fremlin noted that the mistress could not decide how to bid her farewell: "good-bye" implied friendship, while "good afternoon" "“implied an imposition of social hierarchy that may be impractical in such conditions." "106

The explanation given for this uncertainty over class distinctions by Fremlin was a Marxist one. She noted that the mistress in the one-servant suburban house was attempting to preserve a master/servant relationship "suitable only to an age of feudal aristocracy". This was anachronistic because such maids and mistresses inhabited the same economic class: "By this I mean that she has more to lose by a general fall in wages and salaries than by a general fall in rates of interest." ${ }^{107}$ Class was framed as an objective category, external to the individual's sense of identity, and related to the earning power of the husband. The 'servant problem' arose from the cultural disparities between the two women. They might wear the same quality clothes, and verge on finding camaraderie and friendship. But this was socially unacceptable to the mistress, who tried to follow a script of impersonal kindliness and graciousness. Recognizing the impossibility of this script, Fremlin refused the post. Under such conditions, mistress and servant were, in Fremlin's view, 'fellow-victims'; the solution to domestic service problems lay in making clear to mistress and maid their shared economic (class) interests. Idioms of class in the early twentieth century thus ranged from an ambiguous, tentative language, competing with caste, to a materialist construction that dismissed socio-cultural divisions between servants and employers as unreal, and placed the economic realm as fundamental.

What kind of solution to the servant problem did those impersonating servants imagine? Most rejected the idea that better core working conditions might make service more attractive, despite the bluntness of statements such as that of the Labour Party activist Dr. Marion Phillips in her minority memo to the 1919 government inquiry. "I believe that the reason why it is difficult to get servants today is not lack of training, but because servants are dissatisfied with the wages and hours of work." 108 For all its brute obviousness, this was not the message that role reversers were aiming to convey, perhaps because constructing the problem as one of wages and hours made it clear that middleclass women were not going to be able to afford residential domestic help in post World War I Britain. Instead, they preferred an idiom of optimism, reform, and class co-operation, made possible through their own agency as emissaries and intermediaries between classes. This also depended on their being as (or more) capable than working class women of efficiently performing domestic work. In this sense, their work as domestic servants was not intended to capture the experiences of servants, but to construct their own agency and identity, through a recovery of the authority to describe and shape domestic affairs that had been eroded for middle class mistresses confronted with unruly domestic servants. This was not always a successful strategy; some- 
times the intentions of impersonators were mocked and their reversals reversed. Elizabeth Banks's impersonation prompted a satirical reply in the Lady's Pictorial, in which "Mary Jane, a housemaid" wrote of her attempt to learn all about "jernalism" in two days. ${ }^{109}$ And the Daily Chronicle's series on the Countess de Armil derided her lack of ability as a parlourmaid which had swiftly lost her the job. Reversals were thus sometimes sent up, as a fabrication of middle-class authority and capability.

Few texts within this genre proposed the solutions to the servant problem that might be imagined to suit the 'modernizing' ethos of the mid-twentieth century, such as the servantless house or domestic technology. Much more common was the assumption that classes would become more balkanized, while retaining the patterns and traditions of service within the different classes. Even those who felt that class would ultimately disappear, such as Fremlin, still imagined a utopia that retained mistress and maid, and fixed their work as female. The residualisation of domestic service that seemed so inevitable two or three decades later was not foreseen. Service was viewed as a permanent feature of British homes, even in the role reversals of the 1950s.

\section{Conclusion}

Role reversal was, of course, an illustration of power as well as a performative resource in the establishment of class boundaries. Those with social and material resources could cross boundaries at will, while others were permanently marooned within the confines of one social identity. The classifications of class were a resource for some, while others were positioned as class. ${ }^{110}$ Middle class men had the privilege of crossing boundaries and 'passing', but it is clear that servant-keeping women also felt empowered to observe, to pass and to classify. Historians have foregrounded the traditionally male pleasures of 'the right to look', or to act as flâneur in modern urban societies-a form of pleasure that was increasingly available to women. ${ }^{111}$ But the narratives described above suggest that the privileges of 'passing' were not solely visual. Impersonators clearly accessed other pleasures which extended beyond the gaze-the gratification of performance, disguise, adoption of dress, and somatic features such as smell and gesture. Many mention the pleasure they derived from their sense of performance in a role. Elizabeth Jordan noted that dressed in her red check apron, she felt "like a character in an Austrian musical comedy." "112 Others spoke of learning the 'script' of domestic service. Monica Dickens was explicit about her feelings of being in a production: "you must live in your part, get yourself under the skin of it"

Impersonators were in fact echoing the awareness amongst mistresses and servants that domestic service was an everyday performance in which both servants and employers were invested, though in quite different ways. Servants sometimes had to prompt employers who had not learnt the 'script'. ${ }^{14}$ Writers such as E.M. Delafield exploited the comedy of such performances as 'scripts' 
became increasingly uncertain between the wars, especially at liminal moments, such as hiring and firing. ${ }^{115}$ Examining narratives of role reversal expands our understanding of the vehicles of social authority, from the gaze to the embodied performance or impersonation. Just as theorists of gender such as Judith Butler have foregrounded drag and gender impersonation as not an imitation, but a dramatization of "the signifying gestures through which gender itself is established," so class-crossing is simply one amongst many cultural performances which establish the (gendered) norms of social class. ${ }^{116}$

Descriptions of impersonation also provide us with an expanded sense of the arenas or sites at which class and gender might interactively be established. The languages and practices of 'public' arenas of city centres, workplaces and civic institutions have long been seen as central to the ongoing enactment of class. ${ }^{17}$ Recent work in gender history has disrupted our sense of what is 'public' and 'private', and domestic service intensifies this disruption. ${ }^{118}$ As a workplace within a home, domestic service is located ambiguously, as neither private nor public. Its prominence as a widely acknowledged 'problem' in British society illustrates the ways in which 'private' and 'public' fail to capture the complex social landscape of class and gender. Servant-keeping homes were places in which authority was exercised, paid workers were engaged or fired, while simultaneously, powerful discourses positioned it as a site of intimacy and privacy. It was these ambiguities which made the middle class home so central in attempts to set the boundaries and markers of class, and also gave it its fascination as a site in which intrepid impersonations might be undertaken. The home represented 'the social', in Denise Riley's words, that 'blurred' and feminized ground between public and private. ${ }^{119}$

Impersonations of servants were not only performed by intrepid social reformers, but were also enacted or reported within the liminal spaces of mass entertainment and leisure. It has been tempting for historians to read narratives of role reversal in domestic service as a contribution to the serious, reformist 'servant question', which was constructed within so many worthy pamphlets and public enquiries. However, the context of entertainment was equally important to the construction of the servant problem, and has been neglected. Role reversals were often undertaken to gain a readership or titillate an audience. Impersonations were parodied in pulp periodicals, fiction or cartoons, and sensationalized in the mass daily press. The servant problem was emphatically not simply an anxious topic discussed at middle class committees or dinner parties, but was a distinct genre of humour. The boundaries of social class were established, or subverted, through laughter and entertainment, as much as through economic means, etiquette, and traditional marks of social standing. This paper illustrates the ways in which social class is given meaning through versions of it that are encountered in the field of culture. ${ }^{120}$

Impersonators chiefly gained authority and self-definition through their power to mimic and ventriloquize social others. There was a strong sense of epis- 
temic advantage given to those who had directly 'experienced' the conditions they wrote about. Expert knowledge was literally embodied, through physical experiences of kneeling to scrub steps, of vermin, chapped hands and so on. Some historians have seen this as a refreshing challenge to the authority of the usually male experts by women 'amateurs'. But such women veered into patronage by abandoning their status as observers and speaking 'for' their subjects. Role reversal emerges in this period as a proxy for the voices of workingclass women, though there were increasing opportunities for servants to speak and write for themselves. ${ }^{121}$ Nonetheless, for the first half of the twentieth century, it does not seem to have been imagined that working class women might have an unmediated relationship with 'the public', the press, or the state. Middle class women emerged as the mediators of 'the social', while female domestic servants constituted one of its domains.

The motives of role-reversers became supplemented by new aims as the twentieth century went on. Monica Dickens acknowledged her curiosity about servants, but in contrast to her forebears, she also sought to give her life meaning through domestic work. Part of this 'meaning' would come through the adult status and autonomy gained by having authority over a particular domestic domain. Dickens commented that "it would be marvellous to have the run of a kitchen to mess in to my heart's content." "122 Rather than being menial, domestic tasks were becoming a valorized ingredient in constructing a competent female subjectivity. Those 'role reversers' of the 1950s also spoke of their enjoyment of cooking, or simply found domestic service to be well paid. They barely perceived any social transgression in taking domestic work, and did not perceive their choice of job as needing any special explanation. Cleaning and cooking had lost their salience as prime realms in which class boundaries might be demonstrated. The later role reversal narratives were much less centred on establishing divisions between working- and middle-class women, and instead highlighted other class divides; it became easier to laugh at upper class women than those of the working classes. And the 'service question' could be expanded to include much broader social groups, and even men.

The power to 'perform class' and impersonate domestic servants has been linked to the late-nineteenth and early-twentieth century genre of 'slumming', with its detailed, fascinated descriptions of the abject poor, tramps, destitute and slum women and so on. Edwardian and Victorian impersonations of the poor are therefore usually taken as the inspiration for domestic service impersonations. But these role reversals formed part of a different narrative — not the 'social question', but the 'servant question', concerned not with social 'otherness', but with an introspective interest in the identities of middle class women. Many 'class crossers' had taken single-handed jobs, and so had little contact with servants. They were in fact much more curious about mistresses. The role reversal literature served to locate and problematize middle-class subjectivities - the social scripts followed, authori- 
ty practices, the quotidian means of maintaining social distinctions. Rather than provide an 'authentic' account of working class life and experience, impersonation aimed to naturalize difference, establish social distance, and reconstitute middleclass 'mistresshood'.

These texts provide a rare insight into the process of the reformulation of that unstable, anxious and gendered twentieth-century category, 'being middleclass', and its intimate connection with servant-keeping in modern Britain. Classcrossing in domestic service should be read not only as an exercise in power and ventriloquism of working class voices, but also as an attempt to name 'the middle'-the class which Roland Barthes defined as "the social class which does not want to be named," and yet which in the twentieth century was newly self-conscious when confronting its servants. ${ }^{123}$

\section{Notes}

1. Ada (Mrs Cecil) Chesterton, I Lived in a Slum (London: Victor Gollancz Ltd, 1936), 9. I'd like to thank colleagues at the seminars at which this paper was presented (the Cambridge University Centre for Gender Studies, and the British History 1815-1945 seminar at the Institute of Historical Research) for their comments, as well as Leonore Davidoff, for her priceless generosity with sharing her primary sources and intellectual insights.

2. The "British Weekly" commissioners, Toilers in London, or, Inquiries Concerning Female Labour in the Metropolis, ed. John Law (London: Hodder \& Stoughton, 1889), chapter 9.

3. F. Anstey [Thomas Anstey Guthrie], Vice Versa, or Lessons to Fathers (Harmondworth: Puffin, 1981 [1882]).

4. Recent historical work has transformed the study of domestic service through supplementing accounts of social historians by attention to its cultural and symbolic dimensions. This paper centres on British domestic service in the twentieth century, but many of the issues raised were also played out in previous centuries and other national contexts. See Carolyn Steedman, Master and Servant: Love and Labour in the English Industrial Age (Cambridge: Cambridge University Press, 2007); Phyllis Palmer, Domesticity and Dirt: Housewives and Domestic Servants in the United States, 1920-1945 (Philadelphia: Temple University Press, 1989); Alison Light, Mrs Woolf and the Servants (London: Penguin, 2007).

5. Seebohm Rowntree, Poverty: A Study of Town Life (London: Macmillan, 1902), 14, 31.

6. Major, Nineteenth Century, (August 1900): 277

7. Celia Fremlin, The Seven Chars of Chelsea (London: Methuen, 1940), 7.

8. Alison Light, Forever England: Femininity, Literature and Conservatism Between the Wars (London: Routledge, 1991); Judy Giles, The Parlour and the Suburb: Domestic Identities, Class, Femininity and Modernity (Oxford: Berg, 2004); Light, Mrs. Woolf and the Servants.

9. Jerry White describes the employment of daily chars and laundresses by London working-class families, Jerry White, Rothschild Buildings: Life in an East End Tenement Bock, 18871920 (London: Routledge \& Kegan Paul, 1980),140-142.

10. C.V. Butler, Domestic Service: An Enquiry by the Women's Industrial Council (London, G. Bell and Sons, 1916), 28.

11. Homi Bhabha, 'Rethinking Authority', 1996, quoted in Beverley Skeggs, Class, Self, Culture (London: Routledge, 2004), 96. 
12. Mrs. Stuart Macrae, ed., Cassell's Household Guide: A Complete Cyclopadia of Domestic Economy (London: Waverly Book Co., 1912), 842.

13. Jane Ellen Panton, From Kitchen to Garret Hints for Young Householder (London: Ward \& Downey, 1888), 154.

14. Margaret Powell, Below Stairs (London: Pan Books, 1968), 76.

15. For examples of name changing, see Samuel Mullins and Gareth Griffiths, Cap and Apron: An Oral History of Domestic Service in the Shires, 1880-1950 (Leicester: Leicestershire Museums Publications, 1986), 47, 43; and Pamela Horn, Life Below Stairs in the Twentieth Century (Stroud: Sutton Publishing, 2001).

16. Carolyn Steedman, "Servants and Their Relationship to the Unconscious," Journal of British Studies 42 (2003), 334.

17. Quoted in Bridget Hill, Servants: English Domestics in the Eighteenth Century (Oxford: Clarendon Press, 1996), 210-211. On Munby and Cullwick's marriage see Leonore Davidoff, Worlds Between: Historical Perspectives on Class and Gender (New York: Routledge, 1995), 103-150.

18. George Orwell, Orwell's England: The Road to Wigan Pier, ed. Peter Davison (London: Penguin, 2001), 141.

19. Davidoff, 123-125.

20. Rose Mary Crawshay Domestic Service for Gentlewomen: A Record of Experiment and Success, 1896, quoted in Mona Hearn, Below Stairs: Domestic Service Remembered in Dublin and Beyond, 1880-1922 (Dublin: Lilliput Press, 1993), 20.

21. Lady Colin Campbell, Etiquette of Good Society (London: Cassell \& Co., 1911), 44.

22. Davidoff, 112.

23. Munby, quoted in Davidoff, 129.

24. The Diaries of Hannah Cullwick, Victorian Maidservant, ed. Liz Stanley (London: Virago, 1984), 266-267.

25. Powell, , 72.

26. Rosina Harrison, Rose: My Life in Service (London: Cassell, 1975), 144. Ada Chesterton narrated a similar tale about an elderly maidservant, who stole her mistress's things, her mistress believed, because "she feels in a curious sort of way that by possessing them she has a part of me." Ada Chesterton, Women of the Underworld (London: Stanley Paul, 1928), 117. 27. Betty Miller, 'Alfred', Horizon 107 (November, 1948), 338-339, 340.

28. Carolyn Steedman's work reminds us of the eighteenthcentury traditions of servants deploying cultural and legal resources to 'answer back' and reverse the class and gender polarities of cultural authority. Steedman, "Poetical Maids and Cooks Who Wrote," Eighteenth-Century Studies 39, no. 9 (2005), 1-17.

29. Kathlyn Oliver, Common Cause, 7 Dec 1911, 622

30. 'Liberty', The Queen, 4 Sept 1915, p. 456

31. Quoted in E S Turner, What the Butler Saw: Two Hundred and Fifty Years of the Servant Problem (London, Penguin, 2001), 201.

32. 'Chartered Helps', The Spectator, 21 Jan 1914, p. 78

33. Peel, "the Domestic Service Problem" The Queen, 28 Aug 1915, 414.

34. David Englander, "Comparisons and Contrasts: Henry Mayhew and Charles Booth as Social Investigators" in Retrieved Riches: Social Investigation in Britain, 1840-1914, ed. David Englander and Rosemary O'Day (Aldershot: Scolar Press, 1995), 105-142.

35. David Englander and Rosemary O'Day, Mr Charles Booth's Inquiry: Life and Labour of the 
People In London Reconsidered (London: Hambledon Press, 1993), 49.

36. Englander and O'Day, ed., 15. See Seth Koven's detailed and rich investigation of social investigation and investigative journalism of the poor in Victorian London, Slumming: Sexual and Social Politics in Victorian London (Princeton: Princeton University Press, 2004).

37. P. Keating, Into Unknown England, 1866-1913 (London: Fontana, 1976). M.A. Crowther, "The Tramp," in Roy Porter, ed., Myths of the English (Cambridge: Cambridge University Press, 1992), 91-113; Mark Freeman, “Journeys into Poverty Kingdom': Complete Participation and the British Vagrant, 1866-1914” History Workshop Journal, 52 (2001): 99121.

38. James Greenwood ['Amateur Casual'], 'A Night in a Workhouse', Pall Mall Gazette, 1215 Jan 1866; Koven, Slumming, chapter 1. Between 1866 and 1875, role reversal had become highly debated in Britain due in part to the notorious Tichborne case, in which an Australian butcher impersonated a dead British aristocrat, but eventually lost his case in the courts. Journalists such as George Sims explicitly referred to this case in their tales of penetrating London slums. George R Sims, How the Poor Live (London: Chatto and Windus, 1883), 6.

39. On role reversal in the United States, see Mark Pittenger, "A World of Difference: Constructing the 'Underclass' in Progressive America," American Quarterly 49, no.1 (1997): 26-65; Eric Schocket, "Undercover Explorations of the 'Other Half, or the Writer as Class Transvestite," Representations 64 (Autumn 1998): 109-133; Jean Marie Lutes, "Into the Madhouse with Nellie Bly: Girl Stunt Reporting in Late Nineteenth-Century America," American Quarterly 54, no. 2 (2002): 217-253.

40. Jack London, The People of the Abyss (London: Isbister and Co, 1903), 1.

41. London, 12.

42. J.S .Bratton, "Beating the Bounds: Gender Play and Role Reversal in the Edwardian Music Hall," in The Edwardian Theatre: Essays on Performance and the Stage, ed. Michael R. Booth and Joel H. Kaplan (Cambridge: Cambridge University Press, 1996). Peter Bailey has pointed to the class reversals and impersonations both on and off stage within music-halls, as prostitutes dressed up as 'respectable' ladies, and middle class women's fashion tended towards an impersonation of the demi-monde. Peter Bailey, "Conspiracies of Meaning: Music-Hall and the Knowingness of Popular Culture," Past and Present (1994): 161-162.

43. J.H. Stallard, The Female Casual and Her Lodging (London, Saunders, Otley \& Co., 1866) quoted in Koven, 186, 54.

44. Judith Walkowitz, City of Dreadful Delight: Narratives of Sexual Danger in Late-Victorian London (London: Virago, 1992); Judith Walkowitz, "The Indian Woman, the Flower Girl and the Jew: Photojournalism in Edwardian London," Victorian Studies 42, (1998): 3-46.

45. Potter wrote of her experiences in "Pages from a Work-girl's Diary," Nineteenth Century 25 (September, 1888), 301-314. See also Deborah Epstein Nord, The Apprenticeship of Beatrice Webb (Amherst: University of Massachusetts Press, 1985), 165-167.

46. Banks's impersonations are discussed in detail in Koven, chapter 3.

47. G.R. Sims, Biographs of Babylon: Life Pictures of London's Moving Scenes (London: Chatto and Windus, 1902), 139-157.

48. Mary Higgs, Glimpses Into the Abyss (London: P.S. King and Son, 1906), vii.

49. Constance Lytton, Prisons \& Prisoners: Some Personal Experiences (London: Heinemann, 1914), 238-241.

50. Ada (Mrs. Cecil) Chesterton, In Darkest London (London: Stanley Paul and Co., 1926); Ada (Mrs. Cecil) Chesterton, I Lived in a Slum. In Darkest London was initially a series of arti- 
cles in the Sunday Express, in 1925.

51. Chesterton, Women of the Underworld, 44.

52. Chesterton, In Darkest London, 25.

53. Higgs, Glimpses into the Abyss, 194.

54. Elizabeth Banks, Autobiography of a Newspaper Girl (London: Methuen and Co., 1902), 89.

55. See Barbara Onslow, "New World, New Woman, New Journalism: Elizabeth Banks, Transatlantic Stuntwoman in London," Media History 7, no.1 (2001): 7-15.

56. Banks, xiv.

57. Seth Koven has explored the complexity of the "philanthropic motive", arguing that while slumming meant some financial and lifestyle sacrifices, the career prospects of middle class individuals were advanced through their work, as well as fulfilling their psycho-sexual desires. Koven, 285-286.

58. Elizabeth L Banks, Campaigns of Curiosity: Journalistic Adventures of an American Girl in London (London: Cassell and Co., 1894), 73.

59. Banks, Campaigns of Curiosity, 81.

60. Banks, Autobiography, 83.

61. G. Bernard Shaw, Pygmalion: A Romance in Five Acts (New York: 1914); J.M. Barrie, The Admirable Crichton, in Peter Pan and Other Plays (Oxford: Clarendon Press, 1995).

62. Giles, 65-67.

63. Ursula Bloom, Mrs Bunthorpe's Respects: A Chronicle of Cooks (London: Hutchinson, 1963), 23.

64. Bloom, 81.

65. Butler, 5 .

66. F. B S. The Queen, 18 Sep 1915, 523.

67. Violet M. Firth, The Psychology of the Servant Problem; A Study in Social Relationships (London: The CW. Daniel Co., 1925), 8.

68. Firth, 14.

69. Firth, 7-8.

70. Firth, 39. On the meanings of surburbs and modernity, see Giles, chapter 1.

71. Firth, 46.

72. E.M. Wood, Chair, Report to the Committee Appointed to Enquire Into the Present Conditions as to the Supply of Female Domestic Servants, Ministry of Labour (London: HMSO, 1923), 8.

73. See for example Marchioness of Londonderry, "A new Phase of Domestic Service", Good Housekeeping, November 1922.

74. K. Dewan, The Girl (London: G. Bell \& Sons, 1921), 178.

75. Wood, 17.

76. Priestley, "Servants," Saturday Review, 19 March 1927, 428

77. "Rest hour in the kitchen," Daily Chronicle, 4 Feb 1924.

78. "What's wrong with domestic service?," Manchester Guardian, 14 Nov 1930; "Slaves of the Cap," The Times, 28 Apr 1931.

79. 'Domestic Service, a personal experience', E.V.P., Manchester Guardian, 1 December 1930.

80. Joanna Bourke, "Housewifery in Working-Class England, 1860-1914," in Women's Work: The English Experience, 1650-1914, ed. Pamela Sharpe (London: Arnold, 1998), 332358.

81. Our Freedom and Its Results, ed. Ray Strachey (London: Hogarth Press, 1936), 146. 
82. Giles, 84.

83. Orwell, 146.

84. Monica Dickens, One Pair of Hands (London: M Joseph Ltd., 1939), 274.

85. Dickens, 39.

86. Ibid.

87. Dickens, 253.

88. Fremlin, v. See Judy Giles, "Help for Housewives: Domestic Service and the Reconstruction of Domesticity in Britain, 1940-50," Women's History Review 10, no.2 (2001): 299-323.

89. Fremlin, 86.

90. Mary Cosh, "Kitchen Viewpoint," The Spectator, 23 September 1949, 383.

91. Ibid.

92. The cultural genre of role reversal is still thriving, and women's low paid service sector work still attracts 'campaigns of curiosity.' See Polly Toynbee, A Working Life (London: Hodder and Staughton, 1971); Polly Toynbee, Hard Work: Life in Low-Pay Britain (London: Bloomsbury, 2003); Barbara Ehrenreich, Nickel and Dimed: Undercover in Low-Wage USA (London" Granta Books, 2002).

93. This sense of threat is captured by Mary Booth, Charles Booth: A Memoir (London: Macmillan and Co., 1918), 103, 104.

94. London, 12-14.

95. Nord, 168-169.

96. On the sexualization of domestic servants, see Peter Stallybrass and Allon White, The Politics and Poetics of Transgression (Ithaca: Cornell University Press, 1986); Davidoff, chapter 4; Barry Reay, Watching Hannah: Sexuality, Horror and Bodily De-Formation in Victorian England (London: Reaktion Books, 2002).

97. Jenifer Wayne, Brown Bread and Butter in the Basement; A Twenties Childhood (London, Victor Gollancz: 1973), 10.

98. Firth, 71.

99. See for example "A Word for the Servant," Chambers Journal, July 1906; or Spectator, 3 Jan 1925.

100. Peel, The Queen, 30 Apr 1921, 486, emphasis added.

101. 'Lady Helps' or 'Lady Servants' were experimented with in Britain from the middle of the nineteenthcentury. There were elements of role reversal in these 'Lady Servants' - but those advocating such services did not expect them to act as a servant, but rather as a social equal, who would not carry out the rough work, and would herself require the attentions of servants. They did not therefore transgress social boundaries in a deep sense.

102. Firth, 84 .

103. Dickens, 274.

104. Orwell, 163; Fremlin, vi.

105. Fremlin, 23.

106. Fremlin, 25.

107. Ibid.

108. Marion Phillips memorandum, in Gertrude Emmott (Chair), Report of the Women's Advisory Committee of the Ministry of Reconstruction on the Domestic Service Problem (London: HMSO, 1 March 1919), 6.

109. Onslow, 9.

110. Skeggs, 3 
111. Janet Wolff, "The Invisible Flâneuse. Women and the Literature of Modernity," Theory, Culture and Society 2, no. 3 (1985), 37-46; Judith R Walkowitz, City of Dreadful Delight: Narratives of Sexual Danger in Late-Victorian London (London, Virago, 1992), 16; Mica Nava, "Modernity's Disavowal: Women, the City and the Department Store," in Modern Times: Reflections on a Century of English Modernity, ed. Mica Nava and Alan O'Shea (London: Routledge, 1996), 44.

112. Elizabeth Jordan, As Cooks Go (London: Faber, 1950), 31-32.

113. Dickens, 134.

114. Mona Hearn, Below Stairs: Domestic Service Remembered in Dublin and Beyond, 1880-1922 (Dublin: Lilliput Press, 1993), 6.

115. Delafield published her very popular tales of 'servant trouble' from a mistress's perspective in Diary of a Provincial Lady, in the weekly Time and Tide in 1929. E M Delafield, Diary of a Provincial Lady (London: The Folio Society, 1979).

116. Judith Butler, Gender Trouble: Feminism and the Subversion of Identity (London: Routledge, 1990), vii.

117. Alan Kidd and David Nicholls ed., Gender, Civic Culture and Consumerism: Middle-Class Identity in Britain, 1800-1940 (Manchester: Manchester University Press, 1999).

118. Leonore Davidoff and Catherine Hall, Family Fortunes: Men and Women of the English Middle Class, 1780-1850 (London: Hutchinson, 1987); Lawrence E. Klein, "Gender and the Public/Private Distinction in the Eighteenth Century: Some Questions About Evidence and Analytic Procedure," Eighteenth Century Studies 29 (1995): 97-109; Anna Clark, The Struggle for the Breeches: Gender and the Making of the British Working Class (Berkeley: University of California Press, 1995).

119. Denise Riley, Am I That Name? Feminism and the Category of 'Women' in History (Basingstoke: Macmillan, 1988), 48-49.

120. As Simon Gunn has argued, "Neither economic development nor political interests 'give' any particular social identity, including class. Rather, identities and meanings are formed on the terrain of culture as a result of complex negotiations and conflicts, which may (or may not) take economic and political form." Simon Gunn, "The Public Sphere, Modernity and Consumption," in Kidd and Nicholls, 24.

121. In the 1910s and onwards, more opportunities for servants to speak for themselves to conduct their own reversals - had started to appear, in periodicals and newspapers, autobiographies, and testimony to public and governmental inquiries. Servants' voiceot afraid to sign" their names. Emma M Randall Vickers, The Common Cause, 7 Dec 1911, 622.

122. Dickens, 25.

123. Roland Barthes, 'The Bourgeoisie as a Joint-Stock Company' in Roland Barthes, Mythologies, trans. Annette Lavers (London: Cape, 1972). 